\title{
Sistem Informasi Lembaga Pembinaan Khusus Anak Kelas II Tomohon Berbasis Web
}

\author{
Tirsa Kaunang ${ }^{1}$, Jonathan A. Wijaya ${ }^{2}$, Sondy C. Kumajas ${ }^{3}$ \\ 1,2,3 Program Studi Teknik Informatika UNIMA \\ Email: tkaunang08@gmail.com
}

\begin{abstract}
Correctional Information is public information that is produced and managed by the Directorate General of Prisons, region offices, and correctional technical units related to the administration of prisns in accordance with the provisions of the invitation and other information relating to the public interest. It is obligatory to present correctional information, expecially in LPKA Class II Tomohon, which is still manual, where people who want to see correctional information must come to LPKA Class II Tomohon. Therefore, a web-based information system was created which makes it easy to convey correctional information and also helps in submitting complaints. The research method used in this system is the waterfall which consists od analysis, design, code, and testing. The system modeling tool used is UML and testing uses the blackbox testing method.
\end{abstract}

Keywords - Information System, Web, Waterfall Method, UML

\begin{abstract}
Abstrak - Informasi Pemasyarakatan merupakan informasi publik yang dihasilkan dan dikelolah oleh Direktorat Jenderal Pemasyarakatan, kantor wilayah, dan unit pelaksana teknis pemasyarakatan yang berkaitan dengan penyelenggaraan di bidang pemasyarakatan sesuai dengan ketentuan perundang-undangan serta informasi lain yang berkaitan dengan kepentingan publik. Adapun kendala dalam pemberian informasi pemasyarakatan khususnya di LPKA Kelas II Tomohon dimana masih terkesan bersifat manual dimana masyarakat yang ingin mengetahui tentang informasi pemasyarakatan harus datang ke LPKA Kelas II

Tomohon. Maka dari itu dibuatlah sistem informasi berbasis web yang memudahkan dalam menyampaikan informasi pemasyarakatan dan juga membantu dalam menyampaikan pengaduan. Metode penelitian yang digunakan dalam sistem ini yaitu waterfall yang terdiri dari Analisis, Desain, Pengkodean dan Pengujian. Tools pemodelan sistem yang digunakan adalah UML dan Pengujian menggunakan metode pengujian blackbox.
\end{abstract}

Kata Kunci-Sistem Informasi, Web, LPKA, Metode Waterfall, UML

\section{Pendahuluan}

Lembaga Pembinaan Khusus Anak Kelas II Tomohon, atau yang disingkat LPKA Kelas II Tomohon merupakan Lembaga atau tempat anak didik pemasyarakatan dalam menjalani masa pidana. LPKA Kelas II Tomohon dibangun pada tahun $1981 \mathrm{di}$ atas tanah seluas $59.640 \mathrm{~m}^{2}$ dengan bangunan seluas $39.640 \mathrm{~m}^{2}$ dengan kapasitas 250 orang.

Berdasarkan Peraturan Menteri Hukum dan Hak Asasi Manusia Republik Indonesia Nomor M.HH-01.IN,04.03 Tahun 2011 tentang Pengelolaan dan Pelayanan Informasi dan Dokumentasi Pada Direktorat Jendral Pemasyarakatan, Kantor Wilayah Kementerian Hukum dan Hak Asasi Manusia, dan Unit Pelaksana Teknik Pemasyarakatan dimana dalam pasal 2 ayat 1 disebutkan "Informasi Pemasyarakatan bersifat terbuka dan dapat diakses oleh setiap pengguna informasi, kecuali informasi yang dikecualikan" [1].

Maka dari itu setiap Lembaga Pemasyarakatan juga memiliki tugas untuk memberikan Layanan Informasi Pemasyarakatan kepada masyarakat pengguna Informasi Pemasyarakatan. Pada pasal 2 ayat 3 juga disebutkan "Informasi Pemasyarakatan harus dapat diperoleh setiap Pemohon dengan cepat dan tepat waktu, biaya ringan, dan cara sederhana" [1].
Pemberian Informasi di LPKA Kelas II Tomohon masih menggunakan aplikasi Facebook untuk memberikan informasi berkaitan dengan LPKA atau bahkan masyarakat harus ke LPKA Tomohon untuk memperoleh Layanan Informasi Pemasyarakatan. Masalah lain juga ketika masyarakat ingin melapor atau memberikan pengaduan masih terkesan manual dimana masyarakat diarahkan untuk menghubungi melalui telepon, email, messeger ke akun Facebook LPKA Tomohon bahkan ada yang masih tulis tangan.

Oleh karena itu kami merancang sistem informasi berbasis website sebagai solusi untuk menjawab permasalahan tersebut yang didalamnya dilengkapi dengan Layanan Pengaduan Masyarakat dan Layanan Informasi Pemasyarakatan.

\section{TINJAUAN PUSTAKA}

\section{A. Sistem}

Menurut Mc Load "Sistem adalah sekelompok elemen yang terintegrasi dengan tujuan yang sama untuk mencapai tujuan", sedangkan menurut Tata Sutabri "Sistem adalah sekelompok unsur yang erat hubungannya dengan yang lain, yang berfungsi bersama-sama untuk mencapai tujuan tertentu" [2].

Sistem adalah kumpulan elemen yang saling berkaitan untuk mencapai suatu tujuan tertentu.

\section{B. Informasi}


Menurut Tata Sutabri "Informasi adalah data yang telah diklasifikasikan atau diolah atau diinterpretasikan untuk digunakan dalam proses pengambulan keputusan" [2]. Jadi bisa dikatakan informasi adalah fakta mentah yang sudah diolah.

\section{Sistem Informasi}

"Sistem Informasi merupapakan suatu sistem yang data didefinisikan dengan mengumpulkan, memproses, menyimpan, menganalisis, menyebarkan informasi untuk tujuan tertentu" [3]. Menurut Sutabri sistem informasi adalah suatu sistem di dalam suatu organisasi yang mempertemukan kebutuhan pengelohan transaksi harian. Sistem informasi juga bisa dikatakan sebagai kumpulan subsistem yang berisi data-data tertentu untuk ditampilkan dan berguna dalam pengambilan keputusan [4]. Jadi sistem informasi bisa dikatakan sebagai kumpulan elemen yang saling berkaitan dalam mengumpulkan dan memproses suatu data untuk mencapai suatu tujuan tertentu.

\section{Lembaga Pembinaan Khusus Anak}

Dalam Peraturan Menteri Hukum dan Hak Asasi Manysia Republik Indonesia No. 18 Tahun 2015 Tentang Organisasi dan Tata Kerja Lembaga Pembinaan Khusus Anak, dalam pasal 1 menyebutkan bahwa "Dalam Peraturan Menteri ini yang dimaksud dengan Lembaga Pembinaan Khusus Anak yang selanjutnya disingkat LPKA adalah lembaga atau tempat anak menjalani masa pidana [5].

\section{E. Website}

Website dapat diartikan sebagai sekumpulan halaman yang digunakan untuk menampilkan informasi berupa teks, gambar, video, audio baik yang bersifat statis maupun dinamis yang berbentuk suatu kesatuan yang saling berkait [6]. Website juga bisa diartikan sebagai kumpulan dokumen multimedia (gambar, teks, suara, animasi, video) yang menggunakan protocol HTTP dan untuk mengaksesnya menggunkan browser [7].

\section{F. PHP}

Hypertext PreProcessor atau disingkat PHP merupakan bahasa pemograman yang bersifat server-side programming dimana kode program yang telah diketikkan akan dieksekusi di sisi server sehingga client tidak dapat melihat source code dari kode php yang dibangun [8].

\section{G. HTML}

Hypertect Mark-up Language atau yang disingkat HTML adalah bahasa pemograman untuk menjelaskan suatu halaman website. Dimana strukturnya terdiri dari head dan body. Head merupakan informasi deskripsi dari browser. Sedangkan body merupakan isi konteks yang akan ditampilkan. HTML terdiri dari elemen dan tag dimana tag digunakan untuk mengatur elemen property [9].

\section{[10]}

\section{H. CSS}

Cascading Style Sheets atau yang disingkat CSS adalah skrip yang secara khusus digunakan dalam mengatur tampilan aplikasi web, baik mengatur tinggi elemen, warna teks, warna background, ukuran teks, ukuran gambar, dll. CSS juga merupakan skrip yang digunakan untuk mengatur format atau tampilan halaman HTML [11].

\section{Database}

Database atau basis data merupakan kumpulan data yang saling terhubung/berkaitan dimana disimpan secara bersamasama dengan sedemikian rupa tanpa pengulangan yang tidak perlu [12].

\section{METODE}

\section{A. Metode Pengumpulan Data}

Metode pengumpulan data yang digunakan, yaitu:

1) Observasi, Langkah ini dilakukan untuk melihat dan mengidentifikasi kondisi yang ada di LPKA Tomohon secara langsung.

2) Wawancara, jenis wawancara yang kami lakukan yaitu wawancara mendalam dimana dalam pelaksanaannya lebih bebas bila dibandingkan dengan wawancara tersturktur. Tujuannya untuk menemukan permasalahan secara lebih terbuka dimana pihak yang diajak bicara dalam hal ini LPKA Tomohon dimintai pendapat dan ide-idenya.

\section{$B$. Metode Pengembangan Sistem}

Metode pengembangan system merupakan kerangka kerja untuk merencanakan dan mengendalikan proses pengembangan suatu system informasi. Jadi metode pengembangan system yang kami gunakan untuk mengembangkan Sistem Informasi LPKA ini yaitu menggunakan metode Waterfall [13]. Waterfall merupakan model sekuensial linier (sequential linier) atau alur hidup klasik (clssic life cycle), pengembangan system dilakukan terurut mulai dari analisys, design, code, test/pengujian.

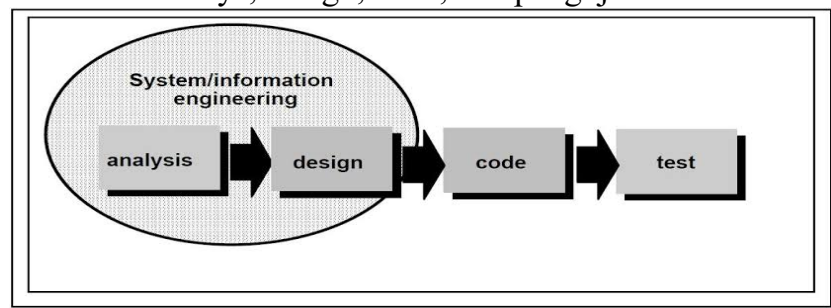

Gbr. 1 Metode Waterfall (Pressman 2000)

\section{HASIL DAN PEMBAHASAN}

\section{A. Analisis Kebutuhan}

Dalam tahap ini kami melakukan tanya jawab dengan Pegawai LPKA untuk mengumpulkan informasi terkait kebutuhan yang diperlukan dalam mengembangkan sistem ini. Hasilnya kami mendapaktakn kebutuhan pengguna dalam website, yaitu:

1) Terdapat 2 pengguna yaitu admin dan usr (pengunjung website)

2) Menyediakan Layanan Pengaduan Masyarakat

3) Dapat menampilkan berita dan gambar yang berkaitan dengan LPKA Tomohon 
4) Menyediakan fitur download sebagai bagian dari Informasi Publik

5) Menyediakan Layanan Informasi Pemasyarakatan.

B. Desain

1) Use Case Diagram

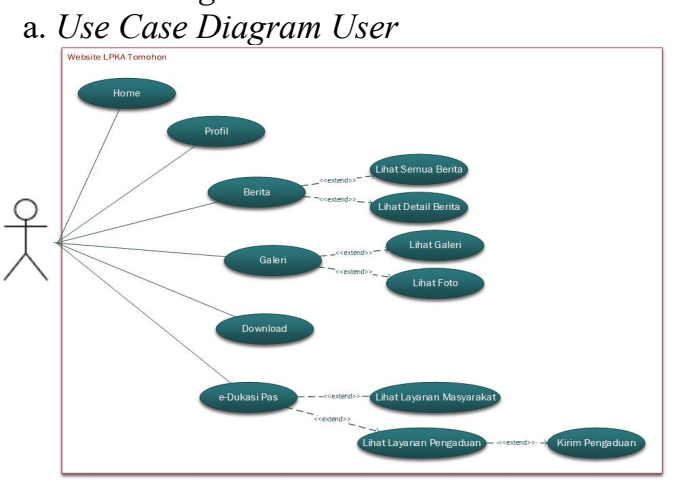

Gbr. 2 Use Case Diagram User

Pada gambar use case diagram user terdapat 1 aktor dalam hal ini user yang memiliki 13 use case yaitu home, profil, berita, download, E-dukasi pas, lihat semua berita, lihat detail berita, lihat galleri, lihat foto, layanan pengaduan, dan layanan informasi, kirim pengaduan.

b. Use Case Diagram Admin

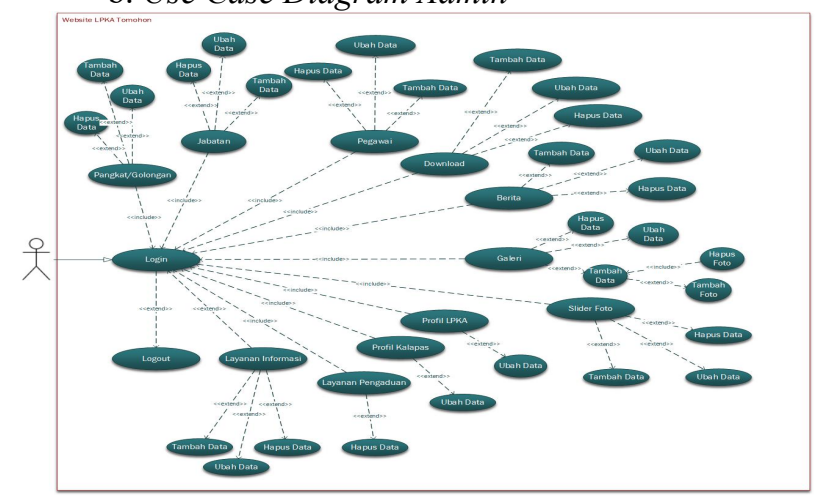

Gbr. 3 Use Case Diagram Admin

Pada gambar usecase diagram admin dengan banyak use case yaitu Login, Pegawai, Pangkat/Golongan, Jabatan, Download, Berita, Galeri, Slider Foto, Profil LPKA, Profil Kalapas, Layanan Pengaduan, Layanan Informasi, Logout, Tambah Data, Hapus Data, Edit Data, Hapus Foto, Tambah Foto.

\section{2) Activity Diagram}

Activity Diagram adalalah aktifitas yang menggambarkan aliran kerja dari sebuah system. Berikut activity diagram dari system informasi LPKA Tomohon:

a. Activity Diagram User

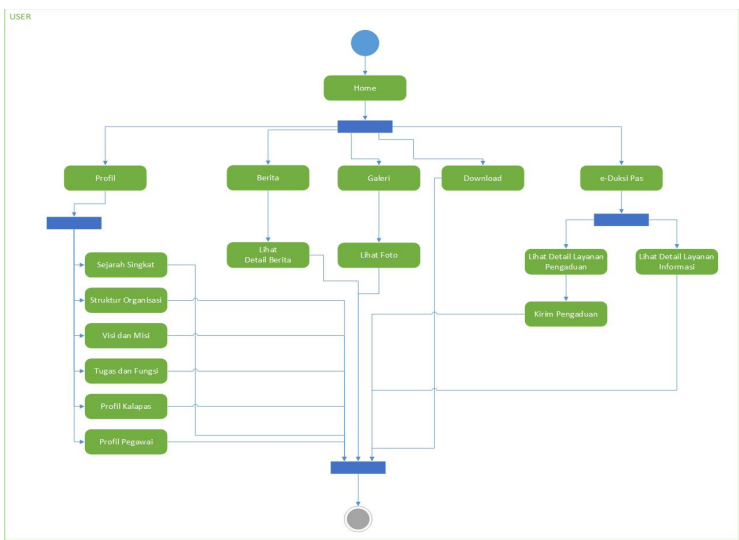

Gbr. 4 Activity Diagram User

Pada gambar activity diagram user menjelaskan bahwa ketika user mengakses website di dalamnya tersedia informasi dari LPKA Tomohon. Ketika mengakses website yang akan ditampilkan terlebih dahulu adalah halaman home, dan ada menu-menu seperti Berita, Profil, Galeri, Download, e-Dukasi Pas. Menu Profil terdapat pilihan tentang profil LPKA bisa dilihat pada gambar seperti Struktur Organisasi, Tugas dan Fungsi, Visi dan Misi, Profil Kalapas, dan Profil Pegawai. Menu Berita terdapat juga fitur untuk melihat berita secara detail. Untuk Menu Galeri sendiri terdapat fitur/menu untuk melihat Foto berdasarkan galleri yang dipilih, Untuk menu e-Dukasi Pas terdapat menu untuk melihat Layanan Pengaduan Masyarakat yang didalamnya User dapat mengirimkan Pengaduan yang berkaitan dengan LPKA Tomohon, juga bisa melihat Layanan Informasi Masyarakat. b. Activity Diagram Admin

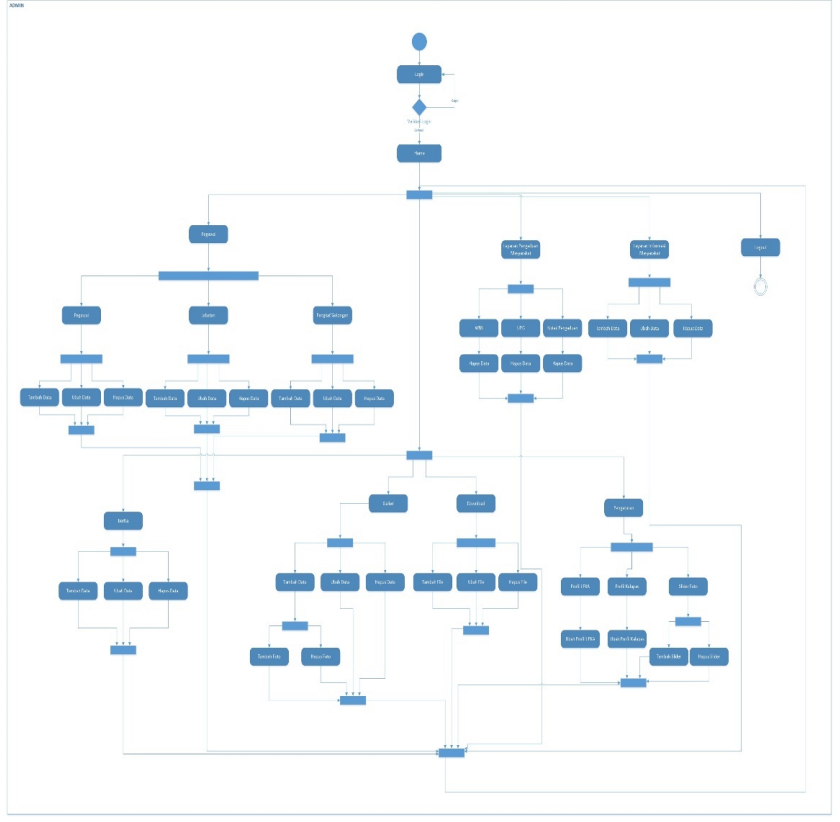

Gbr. 5 Activity Diagram Admin

Pada gambar activity diagram admin menjelaskan bahwa Admin harus melakukan login terlebih dahulu untuk masuk ke dalam sistem (back-end), dimana jika proses login tidak 
berhasil maka harus melakukan login kembali, tetapi jika login berhasil maka admin akan diarahkan ke menu home yang ada di back-end aplikasi, Admin memiliki bebrapa menu yang bisa diakses yaitu Pegawai, Pangkat/Golongan, Jabatan, Berita, Galeri, Download, Layanan Informasi, Layanan Pengaduan, Pengaturan dalam hal ini untuk mengatur Profil LPKA, Slider Foto dan Profil Kalapas. Dimana fungsi-fungsi di dalamnya juga terdapat Tambah, Ubah, dan Hapus Data.

\section{3) Class Diagram}

Class diagram menggambarkan struktur system dari segi pendefinisian kelas yang dibuat.

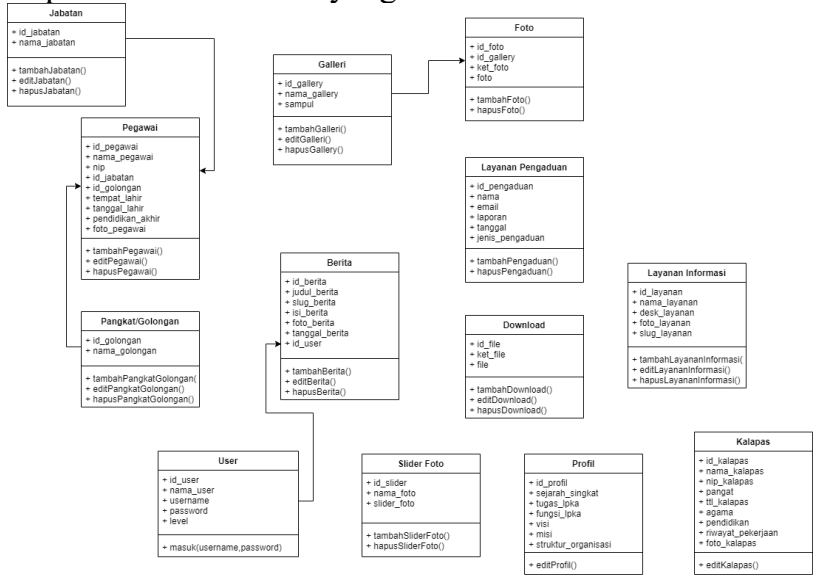

Gbr. 6 Class Diagram

Pada gambar class diagram terdapat 13 tabel yaitu: jabatan, pangkat/golongan, pegawai, galleri, foto, berita, user, layanan pengaduan, download, layanan informasi, slider foto, profil, kalapas.

\section{Code (Pengkodean)}

Pada tahapan ini hasil dari desain di tahap sebelumnya kami implementasikan pada kode program. Kode program yang dibuat berdasarkan hasil analisis masalah dan pemodelan yang telah dilakukan sebelumnya. Framework yang digunakan adalah CodeIgniter, Tamplate dari Bootstrap dan Database menggunakan MySQL.

\section{Test (Pengujian)}

Pada tahap ini dilakukan implementasi aplikasi sekaligus menguji aplikasi.

a. Implementasi Antarmuka

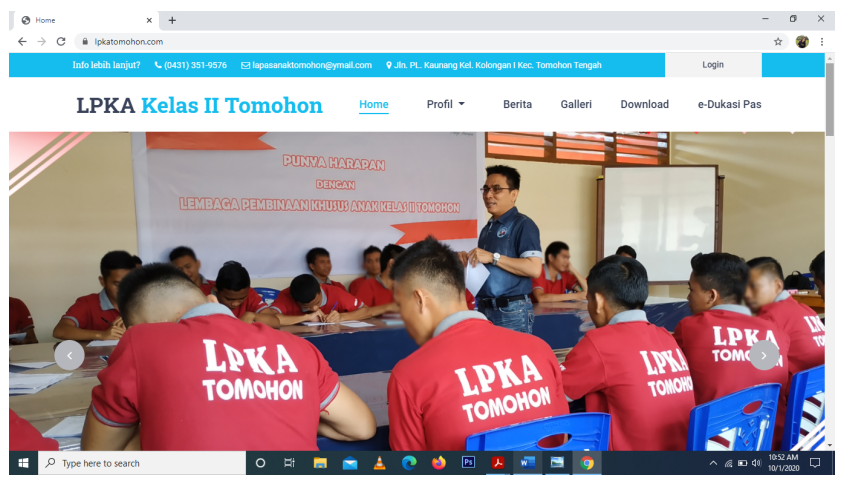

Gbr. 7 Halaman Home

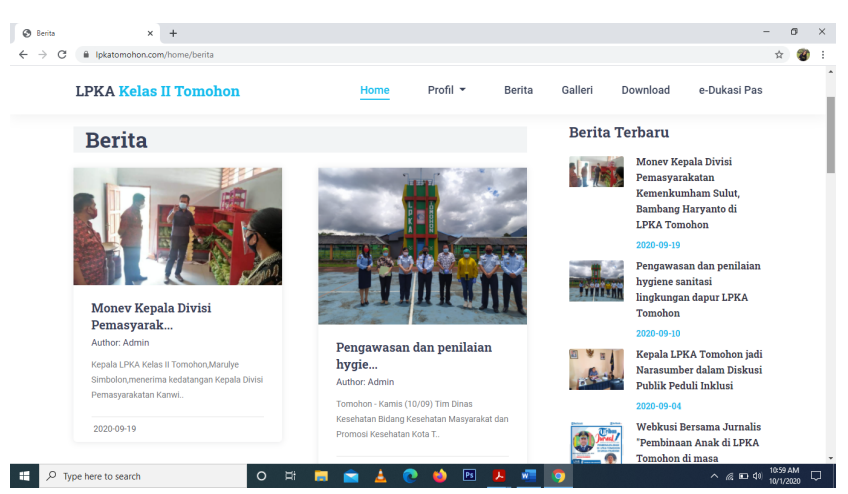

Gbr. 8 Halaman Berita

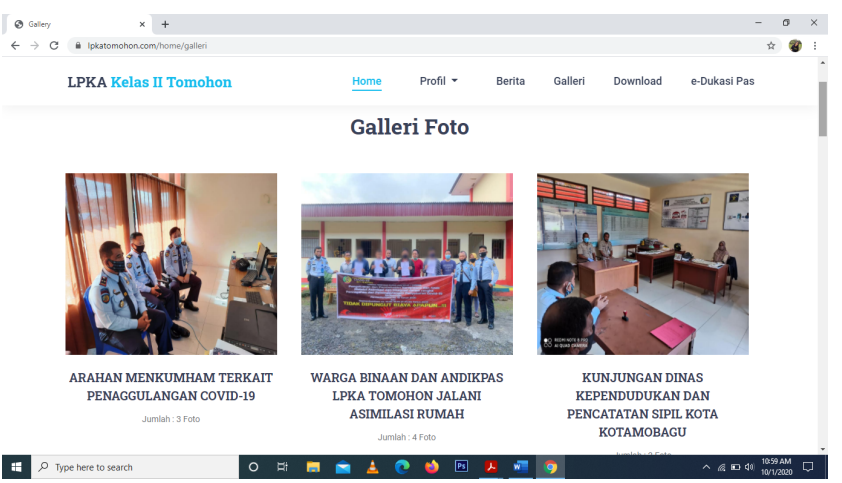

Gbr. 9 Halaman Galleri

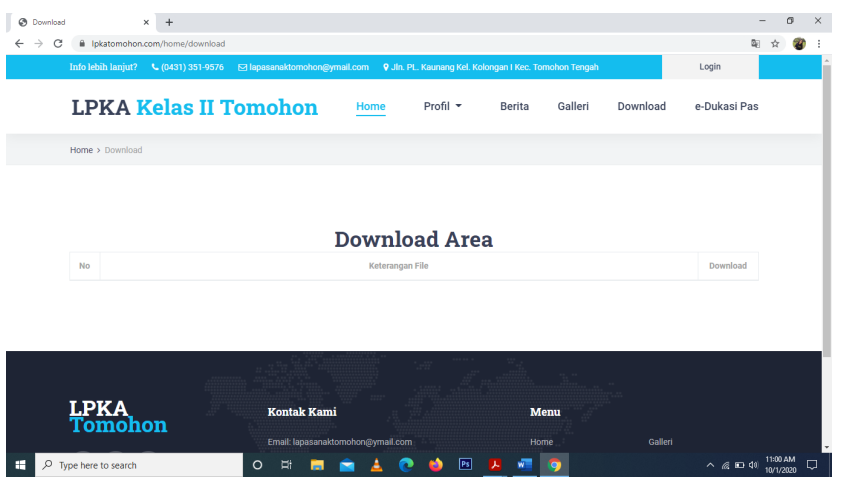

Gbr. 10 Halaman Download 


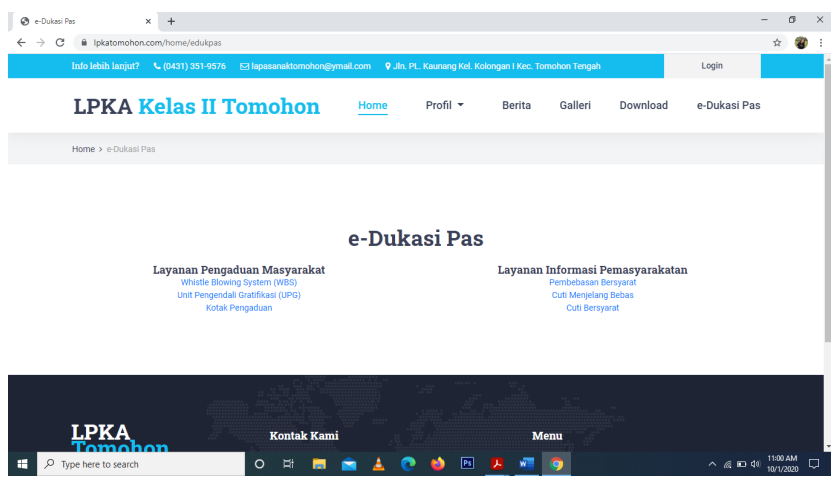

Gbr. 11 Halaman e-Dukasi Pas

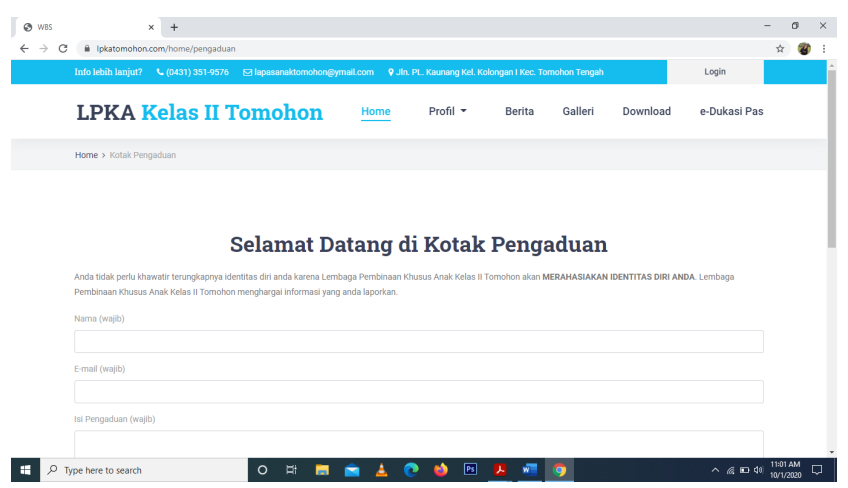

Gbr. 12 Halaman Pengaduan Masyarakat (Kotak Pengaduan)

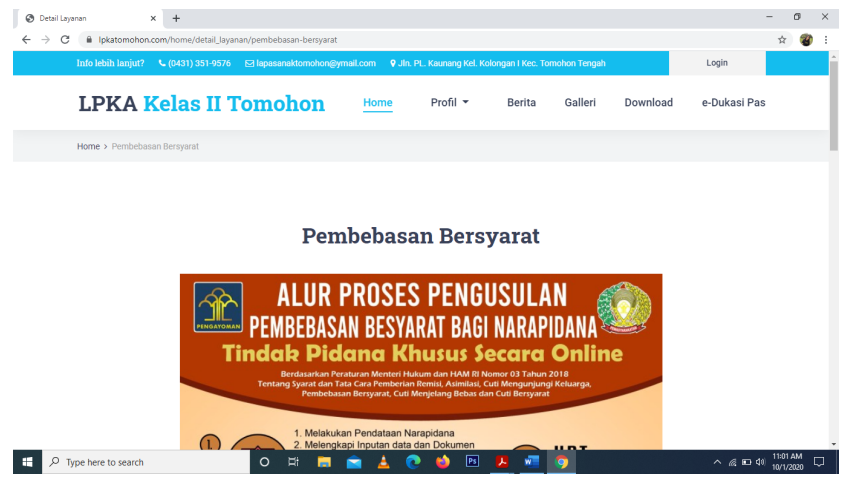

Gbr. 13 Halaman Informasi Pemasyarakatan (Pembebasan Bersyarat)

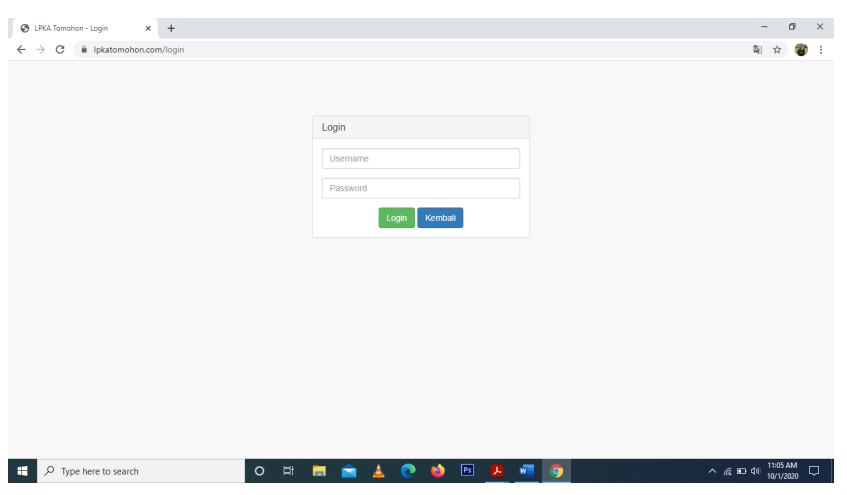

Gbr. 14 Halaman Login

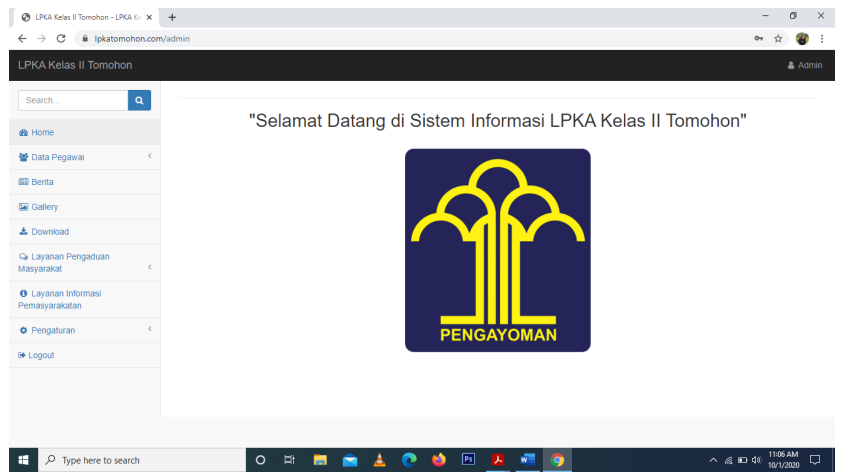

Gbr. 15 Halaman Home (Backend)

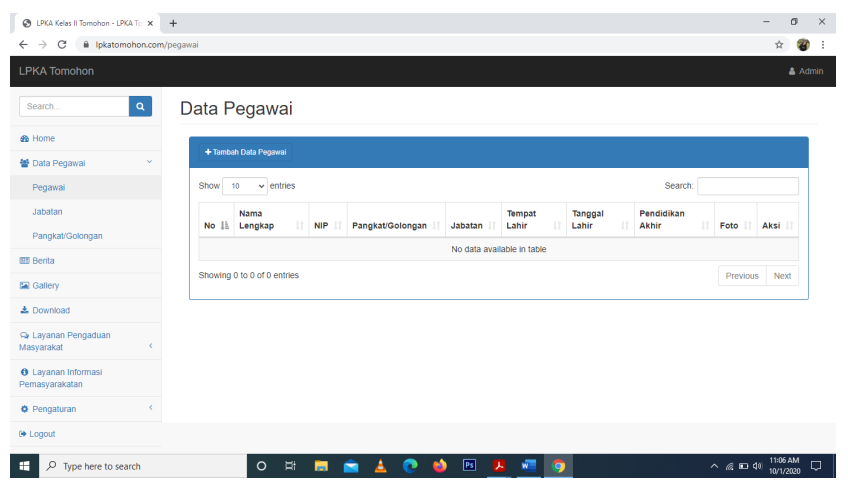

Gbr. 16 Halaman Data Pegawai

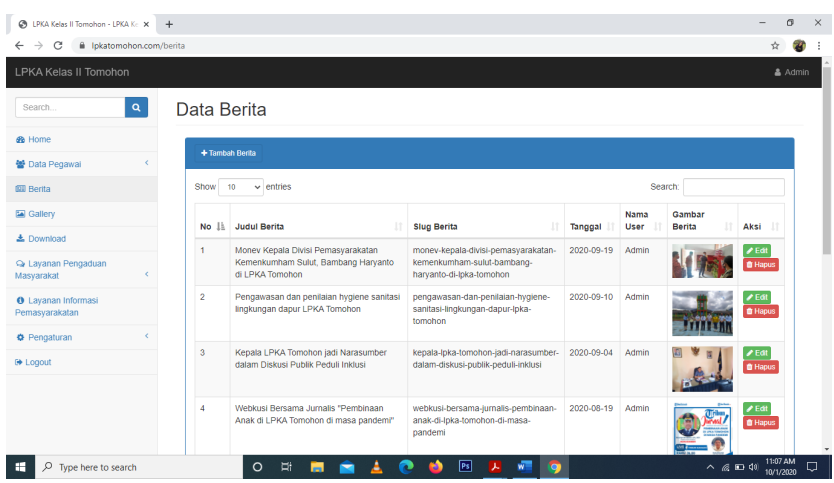

Gbr. 17 Halaman Data Berita

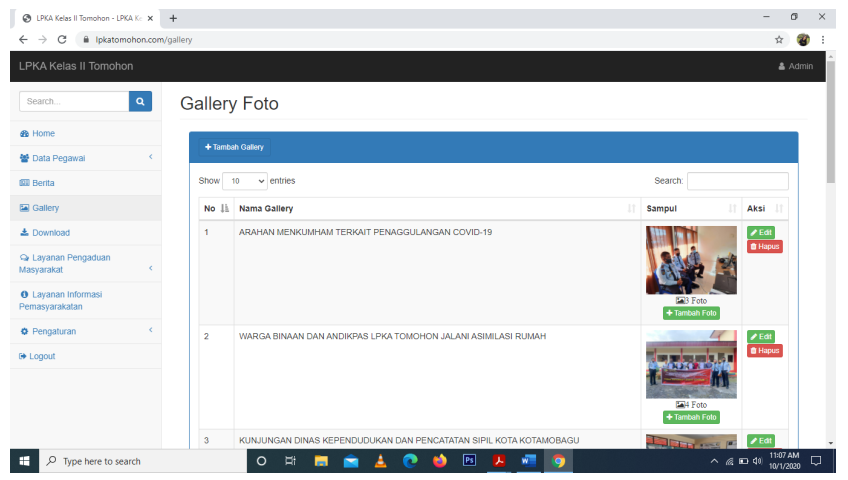

Gbr. 18 Halaman Galleri 


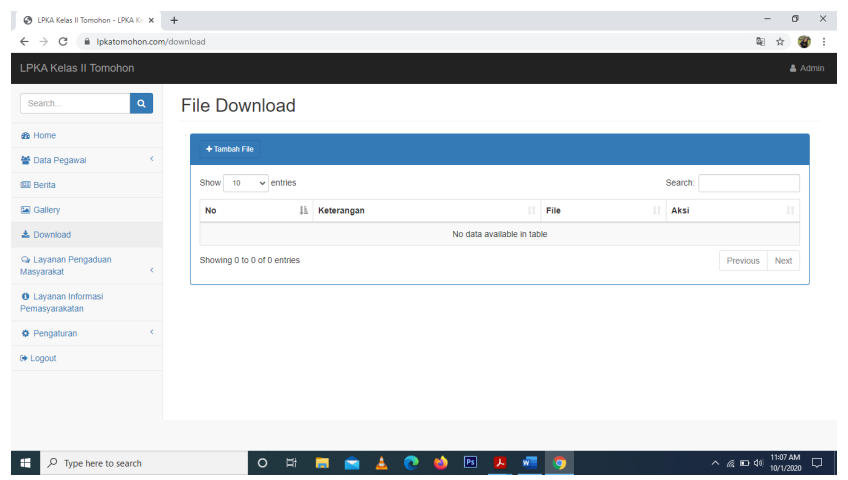

Gbr. 19 Halaman Data Download

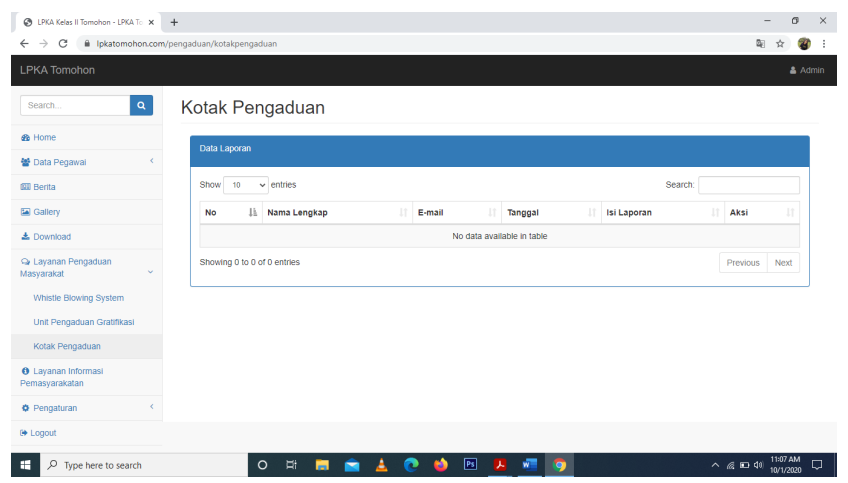

Gbr. 20 Halaman Data Pengaduan Masyarakat (Kotak Pengaduan)

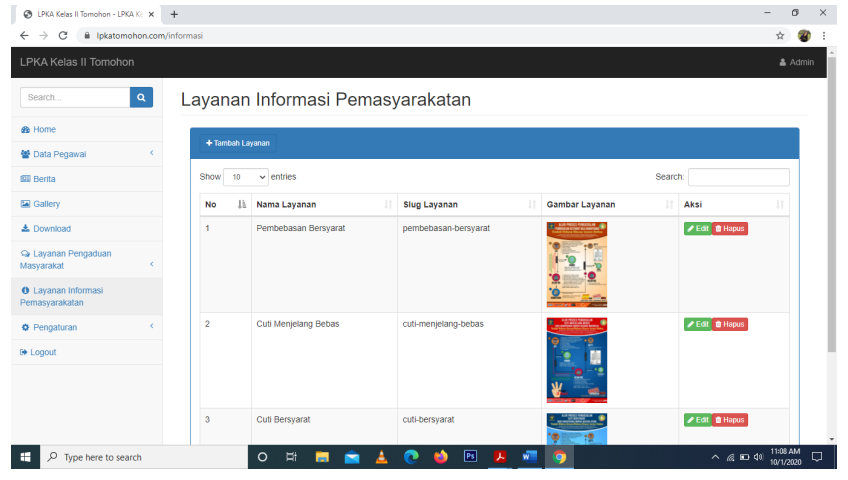

Gbr. 21 Halaman Data Informasi Pemasyarakatan

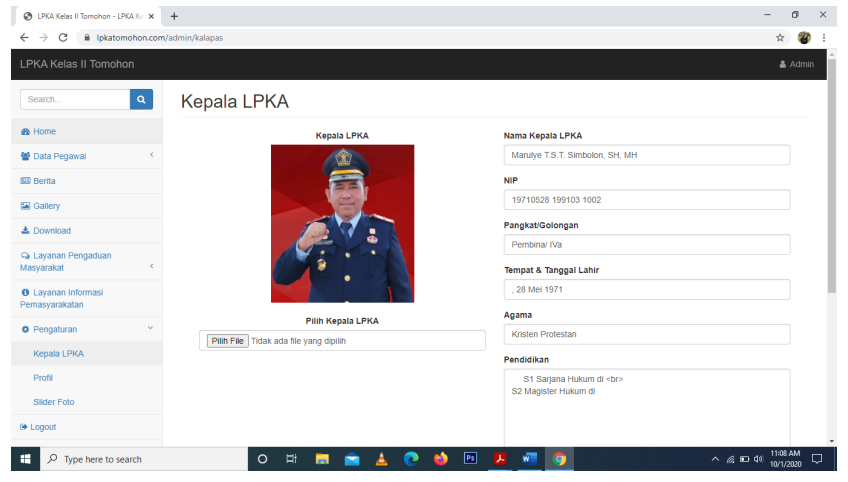

Gbr. 22 Halaman Data Kepala LPKA

\section{b. Pengujian Sistem}

Dalam tahap ini kami melakukan pengujian menggunakan metode pengujian Black Box dan hasil yang diperoleh dari tahap pengujian black box baik dari sisi user dan admin semua berjelan dengan lancar, dan setiap fitur-fitur berfungsi dengan optimal.

\section{KESIMPULAN}

Sistem Informasi Lembaga Pembinaan Khusus Anak Klas II Tomohon telah dirancang dan dibangun sehingga dapat membantu pihak LPKA dalam memberikan informasi yang berkaitan dengan LPKA Tomohon dan mempermudah masyarakat dalam mencari informasi dan mengirimkan pengaduan yang berkaitan dengan LPKA.

\section{DAFTAR PUSTAKA}

[1] KEMENKUMHAM, "Pengelolaan dan Pelayanan Informasi dan Dokumentasi Pada Direktorat Jendral Pemasyarakatan, Kantor Wilayah Kementerian Hukum dan Hak Asasi Manusia, dan Unit Pelaksana Teknik Pemasyarakatan". Republik Indonesia Patent M.HH01.IN,04.03, 2011.

[2] U. M. E. F. Imaniawan, "Sistem Informasi Penjualan Sepatu Berbasis Web Pada Vegas Hyper Putwokerto," Indonesian Journal on Software Engineering, vol. III, no. 2, pp. 82-91, 2017.

[3] V. L. R. T. B. Kaleb, "Penerapan Sistem Informasi Manajemen dan Pengawasannya di Kantor Pelayanan Pajak Pratama Manado," Jurnal EMBA, vol. VII, no. 1, pp. 781-790, 2019.

[4] Y. E. N. Fatimah, "Perancangan Sistem Informasi Perpustakaan Berbasis Web Untuk SMA Islam Sunan Gunung Jati," Jurnal Ilmiah Penelitian dan Pembelajaran Informatika (JIPI), vol. III, no. 2, pp. 130173, 2018.

[5] KEMENKUMHAM, "Organisasi dan Tata Kerja Lembaga Pembinaan Khusus Anak". Indonesia Patent No. 18 Tahun, 2015.

[6] R. A. K. N. Putra, "Sistem Informasi Penjualan Bedcover Berbasis Website," Jurnal Mahasiswa Bina Insani, vol. III, no. 1, pp. 13-22, 2018.

[7] R. A. M. Nasihin, "Sistem Informasi Pengaduan Masyarakat Berbasis Web Dan SMS Gateway Pada Kantor Camat Pontianak Selatan," CYBERNETICS, vol. II, no. 1, pp. 151-161, 2018.

[8] K. Monica, "Rancang Bangun Sistem Informasi Geografis Jalur Angkutan Dalam Kota di Kota Manado Berbasi Web," E-Jurnal Teknik Elektro dan Komputer, vol. V, no. 4, pp. 80-88, 2016.

[9] S. D. ,. Y. U. K. Sally, "Rancang Bangun Aplikasi Pembangkit Halaman HTML untuk Pembuatan Media 
Cetak Digital Berbasi Windows Metro Style," Teknik Pomits, vol. II, no. 2, pp. 413-417, 2013.

[10] N. H. Purwiyati M, "Perancangan Website Sistem Informasi Akademik Pada MTS Negeri Kedu Temanggung," Indonesian Journal on Networking and Security, vol. VII, no. 3, pp. 60-67, 2018.

[11] N. H. Purwiyati M, "Perancangan Website Sistem Informasi Akademik Pada MTS Negeri Kedu Temanggung," Indonesian Journal on Networking and Security, vol. VII, no. 3, pp. 60-67, 2018.

[12] W. H. R. A. dedeh S, "Paket Wisata Pendakitan Gunung Berbasis Web Pada PT. Seven Mountain Adventure Dengan Menggunakan PHP dan MySQL," vol. V, no. 1, pp. 30-38, 2019.

[13] Y. F. R. P. Reza M, "Pengembangan Sistem Informasi Direktori Penceramah "Siramah" Berbasis Website Menggunakan Metode Waterfall," Jurnal Informatika Kaputama, vol. IV, no. 2, pp. 207-215, 2020. 